\title{
TERMINATION OF THE FIDUCIARY DUTY OF BUSINESS ASSOCIATES NOT TO COMPETE FOR THE FIRM'S GUSTOMERS AND SUPPLIERS
}

WHILE THE NATURE of the so-called fiduciary duty ${ }^{1}$ of a director or corporate officer to his corporation, of a partner to his partners, and of an employee to his employers has received a good deal of attention, ${ }^{2}$ there has been little discussion of how, when, under what circumstances, and in what respects it comes to an end. ${ }^{3}$ This paucity of treatment and the resultant vagueness in this area largely reflects an unresolved conflict between two fundamental, yet antithetical, values, each accepted as valid in a competitive society. The first is the desirability of having a business fiduciary discipline his acquisitive instincts so that they will operate vicariously for the benefit, not of himself, but of the firm. ${ }^{4}$ Were this the only consideration, the problem would disappear. A fiduciary would be forbidden to compete for the firm's accounts, if not forever, then for a reasonable time after the termination of the fiduciary relationship. But there is a second value-the desirability of leaving every economically productive person free to use his accumulated knowledge and his abilities to advance his own interests. ${ }^{5}$ If such competition were flatly forbidden, the results, in a competitive society, would not be entirely beneficial.

In general, this fiduciary duty is said to last while the relationship that gives rise to it lasts; in general, it is said to come to an end when the fiduciary leaves the firm. ${ }^{6}$ But there is no sharp dividing line. ${ }^{7}$ In

\footnotetext{
${ }^{1}$ Although this duty is analogous in only some respects to that of a trustee to the beneficiaries of a trust, in the interest of brevity the word "fiduciary" will be substituted hereinafter for the phrase "he who owes a duty to a business associate," and the word "firm" for "the person, persons or corporate entity to whom the duty is owed."

"For general discussion, see 3 Fletcher, Corporations $\$ \S 861,862$ (1947); Crane, Partnership $\$ 68$ (2d ed. I952); Mechem, Partnership $\$ \S$ 170, 171, I72 (2d ed. 1920); Pollock, Partnership $\S 30$ (15th ed. 1952 ).

${ }^{3}$ See, e.g., Note, 64 A.L.R. 782,789 (1929).

"For general discussion, see Dodd, Is Effective Enforcement of the Fiduciary Duties of Cororate Managers Practicable, 2 U. of CHI. L. REv. 194 (1934).

${ }^{5}$ For brief general discussion, see LatTy, Introduction to Business AssociaTroNs 402 , ก. 6 (I95 I).

${ }^{\circ}$ See authorities cited note 2 supra.

${ }^{7}$ E.g., Stem v. Warren, 227 N. Y. 538,125 N.E. $8 \times$ (1920), notes 12,22 and 46 infra (fiduciary duty survives dissolution of partnership by death of partner).
} 
borderline situations the courts have ostensibly imposed liability for breach of the duty on the basis of (a) whether there was any disloyal conduct by the fiduciary before he terminated the relationship, and (b) whether his conduct showed "good faith" toward the firm. " But neither test, as applied, is wholly satisfactory. An examination of the cases suggests, with respect to the first, that there are certain types of duty which persist even after the relationship has been terminatedand others from which the fiduciary may be discharged if he makes a full disclosure to his firm of his intention to compete, even before the association has come to an end. As to the second test, "good faith" does not appear to be used as a term of art by the courts, but rather to characterize approved behavior.

The unsatisfactory results of attempting to apply the "termination" test appear in the long line of partnership cases, where a partner, anticipating the dissolution of the partnership, has sought to capture

${ }^{8}$ E.g., McCourt v. Singers-Bigger, r45 Fed. ro3 (8th Cir. 1906), notes 23, 24 and $4^{2}$ infra (constructive trust imposed where the managing director of a corporation operating a theatre under lease secretly obtained a renewal of the lease in his own name); Red Top Cab Co. v. Hanchett, 48 F.2d 236 (N.D. Cal. 1931), notes 12, 23 and 49 infra (accounting for profits granted where the president of a cab company organized a competing company and enticed drivers from his firm); Williamson v. Monroe, ror Fed. 322 (C.C.W.D. Ark. r900), notes 23, 24 and 46 infra (managing partner required to account for profits where he agreed to secure a contract for the firm but secretly took it on his own behalf); Barden Cream \& Milk Co. v. Mooney, 305 Mass. 645, 26 N.E.2d 324 (1940), notes 12, 13, 23, 24, 46 and 49 infra (tort damages awarded where the managing directors of an insolvent milk company persuaded drivers and customers to transfer to a new firm they had formed); Horn Pond Ice Co. v. Pearson, 267 Mass. 256, 166 N.E. 640 (1929), notes 12,40 and 46 infra (constructive trust imposed on lease taken on ice pond by employees who knew their employer was negotiating for the lease); Holmes v. Darling, 213 Mass. 303, roo N.E. 6II ( $\mathrm{I}_{9} \mathrm{I}_{3}$ ), notes $\mathrm{x}_{9}, 24$ and 46 infra (accounting for profits decreed where partner obtained on his own behalf renewal of agency contract held by partnership to commence at termination of partnership); Sorenson v. Nielson, 240 N.Y. Supp. 250 (Sup. Ct. 1930), notes 12, 20, 24 and 44 infra (constructive trust imposed on import account of the partnership secretly obtained for future employer by partner); Meinhard v. Salmon, 249 N.Y. 458 , 164 N.E. 545 (1928), notes 23,24 and 32 infra (constructive trust imposed on profits from a lease renewal secretly obtained by a joint venturer to commence at the termination of the joint venture); Storey v. Excelsior Shook \& Lumber Co., I98 App. Div. 505, 190 N.Y. Supp. 6140 (1st Dep't 1921), notes 12, 22, 23, 39 and 47 infra (injunction granted against former employees who appropriated records from the files of their employer and while still employed diverted orders to their new firm); Robb v. Green [1895] 2 Q.B. 2, notes 22 and 34 infra (damages and injunction granted where employee, while still employed, copied out his master's order book to make use of it after leaving his employment); Wessex Dairies Ltd. v. Smith [1935] 2 K.B. 80, note 5 I infra (damages granted where milkman solicited customers before leaving his employer's service and setting up for himself). 
a partnership opportunity. ${ }^{9}$ The courts have carefully tried to draw the line between duty and no-duty on the basis of whether the relationship had been terminated at the time the opportunity was captured. But they appear to be manipulating the concepts of "dissolution" and "termination" in order to justify results reached on other grounds. Thus, for example, it has been held that, although dissolution of a partnership at will has been proposed, if negotiations for a final settlement are still in progress, there has been no "termination," and a renewal by one partner in his own name of a lease on partnership premises is a breach of fiduciary duty for which a constructive trust may be imposed. ${ }^{10}$ Yet, in another case, frequently cited with approval, where the partnership owned the majority interest in a small, closely held corporation, the defendant partner escaped imposition of a constructive trust on minority shares secretly purchased by him on the ground that there had been a "termination" upon defendant's announcement of his intention to dissolve the partnership, although the actual winding up process continued for some months after the occurrence of the defendant's alleged breach of duty. ${ }^{11}$ In the first case, it should be noted, however, the remaining partners were offered no opportunity to acquire the lease for the partnership; in the second, they had made an unsuccessful attempt to purchase the stock in question before the defendant secured it. Thus, in the first case, the fiduciary and the firm did not compete upon an equal footing; in the second, they did.

Again, courts have repeatedly penalized the fiduciary who has successfully competed against his firm by either assessing damages against him or imposing a constructive trust upon the whole of his gain on the ground that a part of the conduct complained of took place before the termination of the relationship. ${ }^{12}$ Even where the operations

${ }^{\circ}$ For discussion, see Note, 54 Harv. L. Rev. 1191, 1193 (1941).

${ }^{10}$ Struthers v. Pearce, 5 x N.Y. 357 ( 1873 ).

${ }^{11}$ Bayer v. Bayer, 215 App. Div. 454, 214 N.Y. Supp. 322 (1st Dep't 1926), notes 21,29 and $3 \mathrm{I}$ infra.

${ }^{12}$ E.g., Red Top Cab Co. v. Hanchett, 48 F.2d 236 (N.D. Cal. 1931), note 8 supra, notes 23 and 49 infra; Barden Cream \& Milk Co. v. Mooney, 305 Mass. 645, 26 N.E.2d 324 (1940), note 8 supra, notes $13,23,24,46$ and 49 infra; Horn Pond Ice Co. v. Pearson, 267 Mass. 256, I66 N.E. 640 (x929), note 8 supra, notes 40 and 46 infra; Southwest Pump \& Machinery Co. vo. Forslund, 225 Mo. App. 262, 29 S.W.2d $x 65$ (1930), notes $22,23,38$ and 47 infra (the president of a firm obtained agreement from suppliers that they would supply him when he went into business for himself); Sorenson v. Nielson, 240 N.Y. Supp. 250 (Sup. Ct. 1930), note 8 supra, notes 20, 24 and 44 infra; Storey v. Excelsior Shook \& Lumber Co., 198 App. Div. 505, x90 N.Y. Supp. 614 (xst Dept 1921 ), note 8 supra, notes 22, 23, 39 and 47 infra; Stem v. Warren, 227 N.Y. 538, 125 N.E. 811 (1920), note 7 stpra, notes 22 and 46 infra (a letter written by surviving partner charged with winding up partnership affairs suggesting that partnership contract be cancelled and renegotiated with himself). 
have been almost simultaneous, as where the ingenious executives of a milk company resigned on a Saturday afternoon, telling its drivers to report Monday morning at a new wharf at which they were to pick up milk from a competing supplier to deliver to the firm's customers, a constructive trust has been imposed on the ground that there had been a "plotting" by the fiduciaries before termination of the employment. ${ }^{13}$ Yet, had the executives discussed among themselves, while still employed and without the knowledge of the firm, the possibility of founding a competing company by more orthodox methods, it is difficult to suppose that a court would have held that they had been "plotting" against the firm, even though competition from the new company when formed might have seriously cut into the profits from the old. ${ }^{14}$ It is suggested that the difficulty was that the fiduciaries in question had sewed up the employees and supplier of the firm before the firm had an opportunity to approach them. The parties were not upon an equal footing.

A recent case ${ }^{15}$ raises the problem in dramatic form. The president of the plaintiff corporation, an incorporated advertising agency, which he had founded and had built up to its present success, had been guilty of certain behavior lapses at his office, at business functions and during interviews with actual and prospective customers. There had been complaints; several accounts had withdrawn from the agency. At first, the president refused to resign, and the defendants, a group of top employees who were also officers and directors of the firm, announced that they would themselves leave the agency unless he did so. He subsequently agreed with the defendants that he would resign and that they should buy him out; but negotiations for the purchase broke down-apparently over the question of whether payment should be made in cash or from profits. The defendants then tendered their resignations as officers and directors, but remained, at the request of the president, to wind up the firm's affairs.

They now began to sound out the firm's accounts and its key subordinates with a view toward forming a new firm, and, when the feasibility of their plan became apparent, notified the president that they had been doing so. A new firm was formed, and, at the end of their terminal period of employment, all the individual defendants except two joined it, taking with them eight accounts, representing over

${ }^{13}$ Barden Cream \& Milk Co, v. Mooney, 305 Mass. 645, 26 N.E.2d 324 (1940), notes 8 and 12 supra, notes $23,24,46$ and 49 infra.

${ }^{14}$ E.g., Lincoln Stores v. Grant, 309 Mass. 417, 34 N.E.2d 704 (194I), notes 22 and 30 infra.

${ }^{15}$ Duane Jones Co. v. Burke, 28I App. Div. 622, I2I N.Y.S.2d I07 (Ist Dep't 1953), modified and aff'd, II N.E.2d 237 (N.Y. 1954). 
half the old firm's total "billings," or advertising expenditures which it handled, and $7 \mathrm{I}$ of its 132 employees, including all heads of departments. Neither employees nor accounts were bound by contract to the plaintiff corporation which now sued for damages, alleging a breach of fiduciary duty. A judgment upon a verdict of $\$ 300,000$ was affirmed by a divided court in the Appellate Division, and appeal was taken to the New York Court of Appeals where it was modified and affirmed.

It is difficult to accept the fact that some of the "disloyal" conduct of the defendant fiduciaries took place before the end of their terminal period of employment and after they had given notice as an adequate basis for the imposition of liability in this case. Under the circumstances, it would appear that the defendants could have achieved substantially the same result had they resigned in a body before approaching any of the firm's customers. Nor does their "bad faith," the fact that they "held a gun"16 to the head of the president of the firm, supply a satisfying rationale for the decision. They could reasonably have believed that he was wrecking the enterprise in which they had a joint interest and could not be persuaded to accept reasonable proposals to improve the situation.

What does justify the decision is the fact that the defendants did not compete with the plaintiff upon an equal footing. They did not disclose to the president their intention to compete until they were sure of its success. Further, they were arguably under an extraordinary duty toward him, in view of both his incapacity and the fact that they comprised the bulk of the firm's management personnel. Most important of all, they succeeded, in the language of the Appellate Division, in carving out a new business from the old without paying for it. ${ }^{17}$ It is perhaps significant that the damages awarded by the trial court approximated the amount by which the sale price negotiated between the parties exceeded the sum of its cash assets-which is perhaps as close as it is possible to estimate the fair market value of the goodwill appropriated by the defendants.

It would seem, then, that there is need of a new statement of the rule under which liability is imposed upon the departing business associate for violation of his fiduciary duty not to compete for the firm's customers and suppliers. Such a statement should be at once more flexible and more precise than that based upon the questions whether the conduct complained of took place before or after termination of the relationship, or whether the departing associate acted in "good faith." The rule which seems implicit in the decisions is that the parties must be on an equal footing to compete.

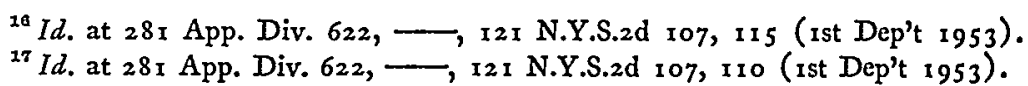


Whether there has been full disclosure of intention to compete is the first and most important test applied to determine whether the associates were in fact competing on such equal footing. Dicta in several cases imply that, if the fiduciary has made a full disclosure to the firm, there are types of assets, at least, which the firm already owns or which it has a reasonable expectancy of acquiring, which he can try to obtain for himself even before he has severed the fiduciary relationship. Thus, in holding a partner constructive trustee of the reversion on a lease of the premises occupied by the partnership, the court remarked that,

... if he designed to act independently of the complainant he should have declared his intention. ${ }^{18}$

And where a partner renewed on his own behalf an agency agreement which had been the principal asset of the partnership, the court said that,

... if the defendant was unwilling to continue in business with the plaintiff after the expiration of their copartnership agreement, he should at least have notified him of that fact, and have given him an equal opportunity to obtain an agency agreement at the expiration of the existing one. ${ }^{19}$

In the same vein, although holding a partner liable for secretly soliciting the firm's one profitable account before resigning, the court observed that,

... It may be a different result would ensue if Nielson had acted differently, if he had been candid instead of silent. ${ }^{20}$

Other tests of equal footing appear to be (I) whether the asset appropriated by the departing defendant fiduciary lay within the ambit of his duty at all ${ }^{21}(2)$ whether he made use of documents or specific

${ }^{18}$ Anderson v. Lemon, 8 N.Y. 236, 239 (1853).

${ }^{10}$ Holmes v. Darling, 213 Mass. 303, 305, 100 N.E. 611, 612 (1913), note 8 supra, notes 24 and 46 infra.

${ }^{20}$ Sorenson v. Nielson, 240 N.Y. Supp. 250, 257 (Sup. Ct. 1930), notes 8 and 12 supra, notes 24 and 44 infra.

${ }^{21}$ Greer v. Stannard, 85 Mont. 78, 277 Pac. 622 (1929) (a director owes no duty to the corporation to refrain, after resigning, from entering a similar field of business); Bayer v. Bayer, 215 App. Div. 454, 214 N.Y. Supp. 322 (ist Dep't 1926), note II supra, notes 29 and 31 infra; Bevan v. Webb [1905] I Ch. 620 (a partner may acquire the reversion of a lease held by the partnership); Trimble v. Goldberg (1906) A.C. 494 (a partner may purchase on his individual behalf property owned by a syndicate although the partnership was formed to acquire shares in the syndicate); Comment, Corporations: The Doctrine of Corporate Opportunities, 31 Calif. L. Rev. 188 (1943); Notes, 39 Col. L. REv. 219 (1939); 54 HARv. L. REv. 1 I9I (1941); 50 MICH. L. REV. 47 I (1952). 
information, e.g., customer lists, specifications, et cetera, which he obtained in his capacity as a fiduciary; ${ }^{22}$ (3) whether he was under an extraordinary duty, perhaps as managing partner or similarly charged corporate officer; ${ }^{23}$ and (4) whether he succeeded in appropriating all, or substantially all, of the firm's goodwill. ${ }^{24}$

${ }^{22}$ Consumer's Company v. William H. Parker, 227 Ill. App. 552 (1923) (constructive trust imposed on lease on employer's premises obtained by employee who learned in the course of his employment of negotiations for renewal of the lease); Lincoln Stores v. Grant, 309 Mass. 417, 34 N.E.2d 704 (1941), note 14 supra, note 30 infra; Southwest Pump \& Machinery Co. v. Forslund, 225 Mo. App. 262, 29 S.W.2d I65 (1930), note 12 supra, notes 23, 38 and 47 infra; Storey v. Excelsior Shook \& Lumber Co., 198 App. Div. 505, 190 N.Y. Supp. 614 (1st Dep't 1921), notes 8 and 12 supra, notes 23,39 and 47 infra; Stem v. Warren, 227 N.Y. 538,125 N.E. 811 (1920), notes 7 and 12 supra, note 46 infra; New York Auto v. Franklin, 49 Misc. 8, 97 N.Y. Supp. 781 (1905), aff'd, 134 App. Div. 908, II8 N.Y. Supp. I127 (4th Dep't 1909), aff'd, 202 N.Y. 557, 95 N.E. 1134 (1911), notes 28 and 37 infra (after leaving the firm, an employee may not make use of drawings and diagrams prepared in the course of his employment); Robb v. Green [1895] 2 Q.B. 22, note 8 supra, note 34 infra; Lamb v. Evans [1893] I Ch. 218, note 35 infra (a writer hired to compose captions for a publisher's guide may not sell the same captions to a subsequent employer).

${ }^{23}$ McCourt v. Singers-Bigger, 145 Fed. 103 (8th Cir. 1906), note 8 supra, notes 24 and 42 infra; Williamson v. Monroe, xox Fed. 522 (C.C.W.D. Ark. 1900), note 8 supra, notes 24 and 46 infra; Red Top Cab Co. v. Hanchett, 48 F.2d 236 (N.D. Cal. 1931), notes 8 and I2 supra, note 49 infra; Barden Cream \& Milk Co. v. Mooney, 305 Mass 645,26 N.E.2d 324 (1940), notes 8, 12 and 13 supra, notes 24,46 and 49 infra; Southwest Pump \& Machinery Co. v. Forslund, 225 Mo. App. 262, 29 S.W.2d 165 (1930), notes 12 and 22 stipra, notes 38 and 47 infra; Meinhard v. Salmon, 249 N.Y. 458, I 64 N.E. 545 (1928), note 8 supra, notes 24 and 32 infra; Storey v. Excelsior Shook \& Lumber Co., 198 App. Div. 505, x90 N.Y. Supp. 614 (rst Dep't 1921), notes 8, 12 and 22 supra, notes 39 and 47 infra; Clegg v. Edmondson, 8 De G.M.\& G. 787, 44 Eng. Rep. 595 ( 1857 ), notes 24 and 45 infra (giving notice of dissolution of the partnership does not discharge the managing partner from liability when he subsequently acquires the mining lease formerly held by the partnership); Cook v. Deeks [1916] I A.C. 554, notes 43 and 46 infra (the managing directors of a construction firm are not discharged from liability by a stockholder's vote ratifying their acquisition on their individual bchalf of a contract which was a reasonable business opportunity of the corporation).

${ }^{24}$ McCourt v. Singers-Bigger, 145 Fed. I03 (8th Cir. 1906), notes 8 and 23 supra, note 42 infra; Williamson v. Monroe, tor Fed. 322 (C.C.W.D. Ark, 1900), notes 8 and 23 supra, note 46 infra (contracting partnership formed to build section of railway roadbed, one partner appropriates contract for further section); Barden Cream \& Milk Co. v. Mooney, 305 Mass. 645, 26 N.E.2d 324 (1940), notes 8, 12, 13 and 23 supra, notes 46 and 49 infra; Holmes v. Darling, 213 Mass. 303,100 N.E. $6 \mathrm{II}_{\mathrm{I}}$ (1913), notes 8 and 19 supra, note 46 infra (agency contract comprising chief asset of partnership); Sorenson v. Nielson, 240 N.Y. Supp. 250 (Sup. Ct. 1930), notes 8,12 and 20 supra, note 44 infra (sole profitable account of partnership); Meinhard v. Salmon, 249 N.Y. 458 , I64 N.E. 545 (1928), notes 8 and 23 supra, note 32 infra; Clegg v. Edmondson, 8 De G.M.\& G. 787, 44 Eng. Rep. 993 (1857), note 23 supra, 
Did the appropriation lie within the ambit of the fiduciary's duty at all? Obviously, the outgoing fiduciary cannot take the firm's "property" with him, ${ }^{25}$ e.g., the desk at which he worked. But it will not do simply to label goodwill as "property,"26 for the outgoing fiduciary is privileged, in the ordinary case, to quit, walk down the street and into a telephone booth, call up the firm's best customer whose account he has been handling, tell the customer that he is now at liberty and going into business for himself, and ask for the customer's account.

Even before the fiduciary leaves the firm, the ambit of his duty is not unlimited. Thus, a director may take advantage of a business opportunity, so long as it is not a "corporate opportunity"; ${ }^{27}$ and, absent specific contract, an employee's invention of a machine creates in his employer no rights (except shop rights-the right of the employer to use the machine in his business without paying a royalty) even though he has worked on his employer's time or made use of his employer's materials or facilities. ${ }^{28}$ Similarly, a partner may engage in business which is "outside the scope of the partnership."20 Even the purchase by the fiduciary, while still with the firm, of a presently non-competing business, with the purpose to turn it into a competing one, has been held not to be a breach of duty. ${ }^{30}$ Likewise, the purchase by a partner of the minority interest in a manufacturing corporation, in which the partnership held the majority of the stock, does not necessarily re-

note 45 infra. But see Washer v. Seager, 272 App. Div. 297,71 N.Y.S.2d 46 (1st Dep't 1947), aff'd, 297 N.Y. 918, 79 N.E.2d 745 (1948) (firm was awarded its principal supply contract on the basis of defendant partner's skill and experience. Defendant partner obtains supplier's agreement to serve new firm he plans to enter after partners quarrel but before dissolution is completed. Held, no liability. Both partners had full opportunity to approach supplier).

${ }^{25}$ For general discussion, see note I supra; for more detailed consideration, see Notes, 39 Col. L. REv. 219 (1939); 54 HARv. L. REv. 1191, I193 (1941).

${ }^{20}$ For a discussion of goodwill as property, see Crane, Partnership Good Will, i 8 VA. L. REv. 65 I (1931); Foreman, Conflicting Theories of Good Will, 22 CoL. L. Rev. 638 (1922); Laube, Good Will in Professional Partnerships, 12 CoRnel. L. Q. 303 (1926); Wright, The Nature and Basis of Legal Goodwill, 24 ILL L. REv. 20 (1929).

${ }^{22}$ See note 21 supra.

${ }^{28}$ New York Auto Co. v. Franklin, 49 Misc. 8, 97 N.Y. Supp. 781 (I905), aff'd, I34 App. Div. 908, Ix8 N.Y. Supp. Ix27 (4th Dep't I909), aff'd, 202 N.Y. 557, 95 N.E. II 34 (I911), note 22 supra, note 37 infra; Gemco Engineering v. Henderson, 82 Ohio App. 324, 7 N.E.2d 742 (1947).

${ }^{20}$ Bayer v. Bayer, 215 App. Div. 454, 214 N.Y. Supp. 322 (Ist Dep't 1926), notes $I \mathrm{I}$ and 21 supra, note $3 \mathrm{I}$ infra (purchase by a partner of minority share in a small closed corporation in which majority shares are held by partnership held outside the scope of the partnership).

${ }^{30}$ Lincoln Stores v. Grant, 309 Mass. 417, 34 N.E.2d 704 (194I), notes 14 and 22 sispra. 
quire the imposition of a constructive trust. ${ }^{31}$ Yet the ambit of the duty is wide, and in the leading case of Meinhard v. Salmon, ${ }^{32}$ where a partnership had been formed for the purpose of managing a lease of a particular parcel of real estate, it was extended to cover a new lease, although such new lease was to begin at the termination of the partnership agreement and to cover a tract several times larger than, and at a rent several times that of, the original parcel.

Once the appropriation has been determined to lie within the ambit of the duty, it is cases which turn on lack of full disclosure which suggest most strongly that termination of the relationship is not a reliable test of liability.

The requirement that the fiduciary shall not use confidential information $^{33}$ and papers which he has acquired in his capacity as a fiduciary to help him obtain control of an asset of the firm likewise applies both before and after termination of the relationship and relates to the one well settled area of this branch of law. The confidential information which the fiduciary may not use includes the list of mail order customers of a breeder of game fowl, which has been built up over a period of years by the proprietor; ${ }^{34}$ section headings for an international "Guide to Merchants and Manufacturers," composed by the fiduciary while employed by the firm, and later appropriated by him for use in a rival publication; ${ }^{35}$ the name by which a firm has been identified to its customers, even though the name may be that of the withdrawing fiduciary ${ }^{36}$ models, patterns and drawings made by the fiduciary while employed to perfect an automobile design (although apparently he may use the basic idea) $j^{37}$ plans, specifications and lists of customers taken from the files of an agency selling pumping machin-

${ }^{31}$ Bayer v. Bayer, $21_{5}$ App. Div. 454, 214 N.Y. Supp. 322 (Ist Dep't 1926). It should be noted, however, that the partnership here was in process of dissolution, and the trial court found as a fact that the other partners had notice of the defendant's intention to acquire the stock.

32249 N.Y. 458,164 N.E. 545 (1928), notes 8 and 23 suppra.

${ }^{33}$ See Lake, The Use for Personal Profit of Knowledge Gained while a Director, 9 Miss. L.J. 427 (1937).

${ }^{34}$ Robb v. Green [1895] 2 Q.B. 2, notes 8 and 22 sutpra.

${ }^{35}$ Lamb v. Evans $[1893]$ y Ch. $2 \times 8$, note 22 supra. The headings were held not subject to copyright, so that no recovery for infringement was possible. Lard Justice Kay, in the course of his opinion, stated the rule, at p. 236, as including every case "where a man has obtained materials while he was in the position of agent for anothermaterials which were obtained by him in the course of that agency and were to be used for the purposes for which his principal had employed him."

${ }^{30}$ Dodge Stationery Co. v. Dodge, 145 Cal. 380,78 Pac. 879 (rgo4).

${ }^{37}$ New York Auto Co. v. Franklin, 49 Misc. 8, 97 N.Y. Supp. 781 (1905), aff'd, 134 App. Div. 908, 118 N.Y. Supp. 1127 (4th Dep't 1909), aff'd, 202 N.Y. 557, 95 N.E. Ir 34 (I9II), notes 22 and 28 supra. 
ery; ${ }^{38}$ and data on the type, quality and quantity of lumber sold by a lumber company to each of its customers. ${ }^{39}$ It does not include the list of customers of an ice company operating in a small town, which is little more than a list of its inhabitants. ${ }^{40}$ This test has been roughly summarized by saying that the fiduciary can carry with him any confidential information which he can remember but may take nothing which has been written down. ${ }^{41}$

Although it is impossible to explain this test on the basis of the termination rule, perhaps the underlying rationale is that the fiduciary has already had an opportunity to ingratiate himself with the customer or supplier in question, and that to permit him to retain actual notes, memoranda, and the like when he leaves the firm will give him an undue advantage-place him on better than an equal footing-in competing with it afterward.

For practical reasons, the last two tests outlined above, i.e., the degree to which the fiduciary has been entrusted with the management of the firm and the extent of the appropriation in relation to the whole goodwill of the firm, are often applicable in the same case. The managing director of a small closed corporation whose sole asset was a theatre lease was held constructive trustee of a renewal for the benefit of his co-founder's daughter and legatee, resident of a foreign country. ${ }^{42}$ Similarly, where the managing directors of a construction firm agreed to get rid of their passive associate and took a contract in their own name for a section of railroad track beyond the one the firm was building, they were held constructive trustees for the firm. ${ }^{43}$ And where a partner in an importing firm went to a competitor, taking with him the firm's one profitable import account, he and the competitor were held constructive trustees for the benefit of the firm. ${ }^{44}$ Likewise, in an early English lease case in which the "equal footing" test is explicitly laid down, the acquisition by a managing partner of the mining lease constituting the sole asset of the firm was said in dictum to be a breach of fiduciary duty so serious that it could not have been cured

\footnotetext{
${ }^{38}$ Southwest Pump \& Machinery Co. v. Forslund, 225 Mo. App. 262, 29 S.W.2d 165 (1930), notes 12, 22 and 23 supra, note 47 infra.

${ }^{30}$ Storey v. Excelsior Shook \& Lumber Co., 198 App. Div. 505, 190 N.Y. Supp. 614 (1st Dep't $\times 921$ ), notes 8, 12, 22 and 23 supra, note 47 infra.

${ }^{40}$ Horn Pond Ice Co. v. Pearson, 267 Mass. 256, 166 N.E. 640 (1929), notes 8 and 12 supra, note 46 infra.

${ }^{21}$ LATTY, op. cit. supra note 5 at 402.

${ }^{22}$ McCourt v. Singers-Bigger, 145 Fed. 103 (8th Cir. 1906), notes 8, 23 and 24 supra.

${ }^{43}$ Cook v. Deeks [1916] I A.C. 554, note 23 supra, note 46 infra.

"Sorenson v. Nielson, 240 N.Y. Supp. 250 (Sup. Ct. 1930), notes 8, 12, 20 and 24 supra; see Note, 30 Col. L. REv. 897 (1930).
} 
by disclosure. ${ }^{45}$ Significantly, then, in Duane Jones v. Burke, considerable emphasis was laid in the decisions of both the Appellate Division and the Court of Appeals on the extent of the appropriation.

To sum up, then, should a business fiduciary plan to leave his firm with a view to competing with it for the accounts of its customers and suppliers, a critical period, during which he is held to a high standard of duty to his firm begins to run. It does not end until that time after he is completely and publicly on his own, when the fact that he was formerly associated with the firm ceases to be of substantial weight with such customers and suppliers in deciding where to place their accounts. The rule which purports to impose liability where there has been self serving conduct on the part of the fiduciary before termination of the relationship deals with one portion of this period only. Such a rule is on the one hand insufficient to control the managing fiduciary, who may be able to appropriate the bulk of the firm's goodwill even after he has left it, and, on the other, too heroic for the ordinary man, who must make sure before he leaves one firm that a place in another is ready for him. Mechanical application of the termination rule may leave the former free, and do little more than educate the latter in techniques of evasion.

A close examination of the cases suggests that the courts are aware of this difficulty, and that, while, ostensibly, they have imposed liability for violation of the termination rule, they are, in fact, basing their decisions upon the necessity to place the parties upon an equal footing. Wherever liability has been imposed, it will appear that the fiduciary has sought to obtain an unequal advantage in the competition. He has Iulled the firm into inaction by concealing his intention to compete, ${ }^{40}$ he has made misstatements to the customer or supplier about the firm's stability, ${ }^{47}$ or has simply sewed them up for himself before the firm was aware that it should take action on its own behalf. ${ }^{48}$ Without

${ }^{45}$ Clegg v. Edmondson, 8 De G.M.\& G. 787, 807, 44 Eng. Rep. 593, 601 (1857), notes 23 and 24 supra.

${ }^{40}$ See, among others, Williamson v. Monroe, ror Fed. 322 (C.C.W.D. Ark. 1 goo), notes 8, 23 and 24 supra; Barden Cream \& Milk Co. v. Mooney, 305 Mass. 645, 26 N.E.2d 324 (1940), notes 8, I2, I3, 23 and 24 supra, note 49 infra; Horn Pond Ice Co. v. Pearson, 267 Mass. 256, I66 N.E. 640 (1929), notes $8, \mathrm{I} 2$ and 40 supre; Holmes v. Darling, $21_{3}$ Mass. 303 , roo N.E. 611 (1913), notes 8, ig and 24 supra; Stem v. Warren, 227 N.Y. 538, 125 N.E. 8 iा (1920), notes 7,12 and 22 supra; Cook v. Deeks, [1916] ז A.C. 554, notes 23 and 43 supra.

${ }^{47}$ Southwest Pump \& Machinery Co. v. Forslund, 225 Mo. App. 262, 29 S.W.2d I65 (1930), notes 12, 22, 23 and 38 supra; Storey v. Excelsior Shook \& Lumber Co., 198 App. Div. 505, 190 N.Y. Supp. 614 (1st Dep’t 1921), notes 8, 12, 22, 23 and 39 supra.

${ }^{48}$ See cases cited in note 46 supra. 
notifying the firm that he was doing so, he has used his daily contact with the firm's employees to influence them to leave it and come with him, ${ }^{49}$ he has borrowed the firm's records and used them without permission or payment, ${ }^{50}$ he has become identified with the firm in the minds of its customers, and has made use of that identification to persuade them to follow him en masse to a new firm..$^{51}$

The simplest and primary technique for placing the parties upon an equal footing, and one frequently suggested in dicta, is to require full disclosure by the fiduciary, both of his intention to compete and of the manner in which he intends to do so. ${ }^{52}$ The requirement of disclosure could be enforced by creating a presumption in favor of the firm that there had been a breach of duty whenever the departing fiduciary took with him the account of a supplier or customer and by placing upon the fiduciary the burden of overcoming the presumption by proving a full disclosure. Where the fiduciary has made use of confidential information or papers, where he is a managing director, or for some other reason in a position of unusual trust, or where the appropriation extends to a substantial portion of the firm's accounts, the presumption might be made conclusive and the fiduciary forbidden to compete unless he paid for what he took. Such a rule would reach the same result as that in Duane Jones v. Burke, and would, by making explicit what already appears to be implicit in the reasoning of courts dealing with this problem, prepare a more flexible and accurate tool for the court of tomorrow.

\section{JANET Hart}

${ }^{40}$ Red Top Cab Co, v. Hanchett, 48 F.2d 236 (N.D. Cal. 193x), notes 8, 12 and 23 supra; Barden Cream \& Milk Co. v. Mooney, 305 Mass. 645, 26 N.E.2d 324 (1940), notes 8, 12, 13, 23, 24 and 46 supra.

${ }^{50}$ For citations, see notes 22 and 34-41 supra.

${ }^{52}$ Duane Jones Co. v. Burke, 281 App. Div. 622, $12 x$ N.Y.S.2d xo7 (1st Dep't 1953), modified and aff'd, II N.E.2d 237 (N.Y. I954), notes 15,16 and 17 supra; Wessex Dairies Ltd. v. Smith [1935] 2 K.B. 8o, note 8 supra.

${ }^{52}$ See notes I 8-20 supra. 